EXPERIMENTAL STUDY

\title{
Functional analysis of the I.3, I.6, pII and I.4 promoters of CYP19 (aromatase) gene in human osteoblasts and their role in vitamin $D$ and dexamethasone stimulation
}

\author{
Anna Enjuanes, Natalia Garcia-Giralt ${ }^{1}$, August Supervía, Xavier Nogués, Silvia Ruiz-Gaspà, Mariona \\ Bustamante $^{1}$, Leonardo Mellibovsky, Daniel Grinberg ${ }^{1}$, Susana Balcells ${ }^{1}$ and Adolfo Díez-Pérez \\ URFOA-IMIM, Hospital del Mar, Universitat Autònoma de Barcelona, E-08003 Barcelona, Spain and ${ }^{1}$ Department of Genetics, Universitat de Barcelona, \\ Barcelona, Spain \\ (Correspondence should be addressed to A Enjuanes; Email: aenjuanes@clinic.ub.es)
}

\begin{abstract}
Objective: Current evidence suggests that extragonadal estrogens play an important role in bone metabolism. Estrogen biosynthesis is catalyzed by P450aromatase, encoded by the CYP19 gene. The aims of this paper were to study CYP19 gene expression in human osteoblasts under several hormone and cytokine treatments and to define promoter regions involved in this regulation.

Methods: CYP19 transcript levels were measured from primary human osteoblasts and MG-63 cells by real-time PCR in basal conditions, and in response to seven different hormones and cytokines. Four promoters of CYP19 gene were cloned upstream of the luciferase gene and transfected into MG-63 cells. The effect of vitamin D and dexamethasone in these promoter activities was evaluated.

Results: Vitamin D and dexamethasone were potent stimulators of CYP19 transcription, while testosterone and $17 \beta$-estradiol stimulated moderately. Promoter pII proved the most potent in driving transient luciferase expression. Promoter I.4 displayed moderate activity, while promoters I. 3 and I.6 were weak. A region upstream of exon I.3, including exon I.6, was identified as containing repressor elements of promoter pII. Promoter I.3 activity was modulated by repressors located within exon I.3, while an enhancer of promoter I.4 was detected within exon I.4. In the absence of fetal calf serum, dexamethasone stimulation was observed on promoters I.3 and I.4, while vitamin D stimulation acted only on promoter I.3.

Conclusions: Four regulatory regions of promoters pII, I.3 and I.4 are relevant to CYP19 expression in human osteoblasts. Vitamin D and dexamethasone modulate transcription through these regions.
\end{abstract}

European Journal of Endocrinology 153 981-988

\section{Introduction}

Osteoporosis, the most common metabolic bone disease in Western society, constitutes an imbalance of the bone remodeling process in favor of bone resorption, leading to decreased bone mineral density and bone quality with an increased propensity to fracture.

The bone phenotypes of several knockout mice, namely, estrogen receptor- $\alpha(\mathrm{ER} \alpha)$-knockout, $\mathrm{ER} \beta$ knockout, double-mutant $\alpha \beta$-knockout and aromatase-knockout mice $(1-4)$ show that estrogens play an important role in bone tissue. In recent years, the discovery in men of an osteoporotic phenotype due to a mutation in the ER $\alpha$ gene, or to mutations in the CYP19 gene, has suggested that non-ovarian estrogen production is relevant in the maintenance of bone mineralization, pubertal growth spurts, epiphyseal fusion, skeletal maturation, and the prevention of osteoporosis, since these men exhibited failed epiphyseal closure, osteopenia and delayed bone age (5-7). Therefore, the understanding of the role estrogens play in both females and males has grown significantly and considerable emphasis has been placed on the regulation of extragonadal estrogen biosynthesis, including bone estrogen production.

Cytochrome P450 aromatase is the key enzyme for estrogen biosynthesis. Aromatase catalyzes the conversion of testosterone to estradiol, of androstenedione to estrone, and of 16-hydroxylated dehydroepiandrosterone to estriol (8). Aromatase is encoded by a single gene, CYP19, localized on 15q21.2. The human CYP19 gene spans about $123 \mathrm{~kb}$ with nine coding exons (exons II to $\mathrm{X}$ ) and several alternative non-translated $5^{\prime}$ exons (9). To date, ten such exons have been described: I.1, I.2, I.3, I.4, I.5, I.6, I.7, 2a, 1f and pII 
(10-13). Regulation of CYP19 expression is achieved by use of alternative tissue-specific promoters, each of which is linked to a specific downstream, untranslated first exon. Differential splicing produces specific transcripts bearing different $5^{\prime}$ ends $(10,14)$. Aromatase activity and CYP19 gene expression have been detected in human cultured osteoblasts $(15,16)$, as well as in the human osteosarcoma cell lines HOS, U2OS and MG-63 (17-21). Several studies have shown that promoter usage and regulation of aromatase gene expression in osteoblasts is specific and different from those of other tissues such as placenta, ovary and adipose tissue $(22-25)$.

In the present study we have investigated the regulation of CYP19 gene expression in primary human osteoblasts (hOBs) and MG-63 cells in response to 1,25 vitamin D3 (Vit D), dexamethasone (DEX), 17 $\beta$ estradiol (E2), testosterone, tumor necrosis factor- $\alpha$ $(\mathrm{TNF}-\alpha)$, interleukin-1 $\beta$ (IL-1 $\beta$ ) and leptin. Moreover, we have examined the use of CYP19 promoters in response to such treatments. We have performed a luciferase reporter assay in the MG-63 cell line using plasmid constructs with several promoters of the CYP19 gene to define regulatory regions relevant to its expression in hOBs.

\section{Materials and methods}

\section{Cell culture}

Human bone cells were obtained from specimens of healthy individuals without remodeling bone disease who had undergone surgery for acute traumatic conditions. The protocol used for primary hOB culture has been previously described (22). Osteoblasts were characterized by alkaline phosphatase activity and osteocalcin synthesis in response to stimulation with Vit D (Roche, Basel, Switzerland). MG-63 cells were purchased from ATCC (http//www.atcc.org). Experimental cultures were grown with Dulbecco's modified Eagle's medium (DMEM) (Invitrogen, Grand Island, NY, USA), supplemented with $20 \%$ fetal calf serum (FCS) (Biological Industries, Kibbutz Beth Haemek, Israel) in primary hOB cultures and with $10 \%$ FCS in MG-63 cultures. In order to synchronize cells, at confluence, culture medium was replaced with DMEM containing 0.1\% BSA (Sigma-Aldrich Química S.A., Madrid, Spain) for $48 \mathrm{~h}$. Subsequently, osteoblast and MG-63 cells were incubated in DMEM for $6 \mathrm{~h}$ with or without FCS and alternative treatments: DEX $10^{-7} \mathrm{~mol} / \mathrm{l}$ (Sigma), Vit D $10^{-7} \mathrm{~mol} / \mathrm{l}, \quad$ E2 $10^{-6} \mathrm{~mol} / \mathrm{l}$ (Sigma), testosterone $10^{-6} \mathrm{~mol} / \mathrm{l}$ (Sigma), recombinant human IL-1 $\beta 10^{-6} \mathrm{~mol} / \mathrm{l}$ (R\&D Systems, Inc., Minneapolis, MN, USA), recombinant human TNF- $\alpha 10^{-6} \mathrm{~mol} / \mathrm{l}$ (R\&D Systems) and recombinant human leptin (10 100 and $1000 \mathrm{ng} / \mathrm{ml}$ ) (R\&D Systems).

\section{Extraction of total RNA and reverse transcription}

Total RNA was prepared from cultured hOBs using Tri Reagent (Molecular Research Center, Inc., Cincinnati, $\mathrm{OH}$, USA) according to the manufacturer's protocols. Reverse transcription of RNA, for first-strand cDNA synthesis was performed using $1 \mu \mathrm{g}$ total RNA and $25 \mathrm{ng} / \mathrm{ml}$ oligo (dT)12-18 primer (Invitrogen) in a final volume of $6 \mu \mathrm{l}$. The reaction was incubated at $70{ }^{\circ} \mathrm{C}$ for $10 \mathrm{~min}$ and immediately chilled on ice. Primer extension was then performed at $42^{\circ} \mathrm{C}$ for 50 min following addition of reaction buffer containing $50 \mathrm{mmol} / \mathrm{l}$ Tris $-\mathrm{HCl}(\mathrm{pH} 8.3), 75 \mathrm{mmol} / \mathrm{l} \mathrm{KCl}$ and $3 \mathrm{mmol} / \mathrm{l} \mathrm{MgCl}, 10 \mathrm{mmol} / \mathrm{l}$ dithiothreitol, $1 \mathrm{mmol} / \mathrm{l}$ of each dNTP and $100 \mathrm{U}$ SuperScript II Rnase $\mathrm{H}^{-}$Reverse Transcriptase (Invitrogen) in a final volume of $10 \mu \mathrm{l}$. The reaction was inactivated by heating at $70{ }^{\circ} \mathrm{C}$ for 10 min. cDNA was stored at $-20^{\circ} \mathrm{C}$.

\section{Study of aromatase mRNA expression by real-time PCR}

Real-time PCR for CYP19 was conducted in a volume of $20 \mu \mathrm{l}$ containing $2 \mu \mathrm{l}$ cDNA (1/10 dilution of reverse transcriptase mixture), $900 \mathrm{nmol} / \mathrm{l}$ each primer, $50 \mathrm{nmol} / \mathrm{l}$ TaqMan-MGB probe (Applied Biosystems, Foster City, CA, USA) and $10 \mu \mathrm{l}$ TaqMan Universal PCR Master Mix $2 \times$ (Applied Biosystems) in the following sequence: $2 \mathrm{~min}$ at $50^{\circ} \mathrm{C}$, followed by 50 cycles at $95^{\circ}$ for $15 \mathrm{~s}$, and then at $60^{\circ} \mathrm{C}$ for $60 \mathrm{~s}$ in 384-well plates with the ABI PRISM 7900 HT Detection System (Applied Biosystems). The sequences of forward and reverse primers were: $5^{\prime}$-ACCCTTCTGCGTCGTGTCAT-3' (exon V) and 5'-TTGCCATGCATCAAAATAACCT-3' (exon VI) respectively, and FAM-Taq-

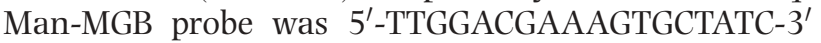
(between exon $\mathrm{V}$ and exon VI). Primers and the TaqMan-MGB probe were designed using the Primer Express software Ver. 1.2 (Applied Biosystems). Realtime PCR for $\beta$-actin was carried out under the same conditions, using a $\beta$-actin Assay on Demand (Applied Biosystems) containing primers and a VIC-TaqManMGB probe. A standard curve for each gene was constructed using multiple dilutions of an external cDNA sample. Results were been analyzed using the SDS TM Applied Biosystems Software Ver. 1.0 and expression levels calculated from a linear regression of the standard curve. Results are given as CYP19 expression vs $\beta$-actin expression (CYP19 relative expression) using arbitrary units. All real-time PCR reactions for each sample were performed in duplicate.

\section{Promoter constructs}

The 5'-flanking region of CYP19 was amplified by PCR from human genomic DNA in a reaction mixture of $50 \mu \mathrm{l}$ containing $100 \mathrm{ng}$ genomic DNA, $60 \mathrm{mmol} / \mathrm{l}$ 
TrisSO $_{4}\left(\mathrm{pH}\right.$ 8.9), $18 \mathrm{mmol} / \mathrm{l}\left(\mathrm{NH}_{4}\right)_{2} \mathrm{SO}_{4}, 0.2 \mathrm{mmol} / \mathrm{l}$ each deoxy-NTP, $0.3 \mu \mathrm{mol} / \mathrm{l}$ of each forward and reverse primer and $1 \mathrm{U}$ Platinum Taq DNA polymerase High Fidelity (Invitrogen). PCR reactions were performed with an initial denaturation step of $94{ }^{\circ} \mathrm{C}$ for $5 \mathrm{~min}$, followed by 40 cycles of denaturation at $94^{\circ} \mathrm{C}$ for $30 \mathrm{~s}$, annealing at $59^{\circ} \mathrm{C}$ for $60 \mathrm{~s}$, and polymerization at $72{ }^{\circ} \mathrm{C}$ for $90 \mathrm{~s}$, with a final elongation step at $72{ }^{\circ} \mathrm{C}$ for $10 \mathrm{~min}$. Primers, $\mathrm{MgSO}_{4}$ concentration and expected size for each PCR are shown in Table 1. After purification, PCR-amplified fragments were digested with KpnI and XhoI restriction enzymes (New England Biolabs, Beverly, MA, USA) and then subcloned into a pGL3-Basic Vector (Promega, Madison, WI, USA) which carries firefly luciferase as its reporter gene. The inserts were sequenced to ensure fidelity of amplified sequences. The constructs were named pGL3/CYP19 (A to H) (Fig. 3).

\section{Transfection and luciferase assays}

MG-63 cells were grown in DMEM with 10\% FCS at $50-80 \%$ confluency and transient transfection was carried out using the FuGene 6 Reagent (Roche). Cells were co-transfected with $2 \mu \mathrm{g}$ of each pGL3/CYP19 construct and $0.5 \mu \mathrm{g}$ of a plasmid expressing $\beta$-galactosidase driven by the SV40 early promoter (pSV- $\beta$ Gal vector) (Promega). After transfection, MG63 cells were incubated in DMEM without FCS for $6 \mathrm{~h}$ and subsequently Vit D $\left(10^{-7} \mathrm{~mol} / \mathrm{l}\right)$ and/or DEX $\left(10^{-7} \mathrm{~mol} / \mathrm{l}\right)$ were added to the medium, either without or with 10\% FCS. MG-63 cells with no treatment were used as a control (with and without FCS). After treatment addition, MG-63 cells were incubated for $24 \mathrm{~h}$ in order to ensure promoter activation and luciferase synthesis, and then lysis was performed with Cell
Lysis Reagent (Roche). MG-63 cells transfected with a pGL3 vector, without insert, were used as a basal expression control. Luciferase and $\beta$-galactosidase assays were performed using the Luciferase Assay System Kit (Promega) and the $\beta$-Gal Reporter Gene Assay Kit (Roche) respectively. Firefly luciferase activities were normalized to $\beta$-galactosidase activities to correct for differences in transfection efficiency. Transfection experiments were replicated four or more times for each construct, and all chemiluminescent assays were performed in duplicate.

\section{Statistical analysis}

All data analyses were performed using the SPSS 11.0 statistical package. Significant differences between any two groups were determined by Student's $t$-test or a Mann-Whitney U-test. When multiple groups were compared, one-, two- or three-way ANOVA was utilized, followed by a Student-Newman-Keuls or Tukey multiple contrast test, when applicable. A value of $P<0.05$ was considered significant.

\section{Results}

\section{Effects of Vit D, DEX, E2, testosterone, TNF- $\alpha$, IL-1 $\beta$ or leptin on CYP19 gene expression}

CYP19 transcript levels were measured by real-time PCR in cultures of primary hOBs (three men and a woman aged 60, 67, 72 and 67 years respectively) and MG-63 cells treated with Vit D, DEX, E2, testosterone, TNF- $\alpha$, IL-1 $\beta$ or leptin, with or without $10 \%$ FCS (Fig. 1). Basal expression was detected in both cell types, but was lower in MG-63 cells and was not affected by FCS. Treatments with either $10^{-7} \mathrm{~mol} / \mathrm{l} \mathrm{DEX}$ or $10^{-7} \mathrm{~mol} / \mathrm{l}$

Table 1 Primers for promoter constructs.

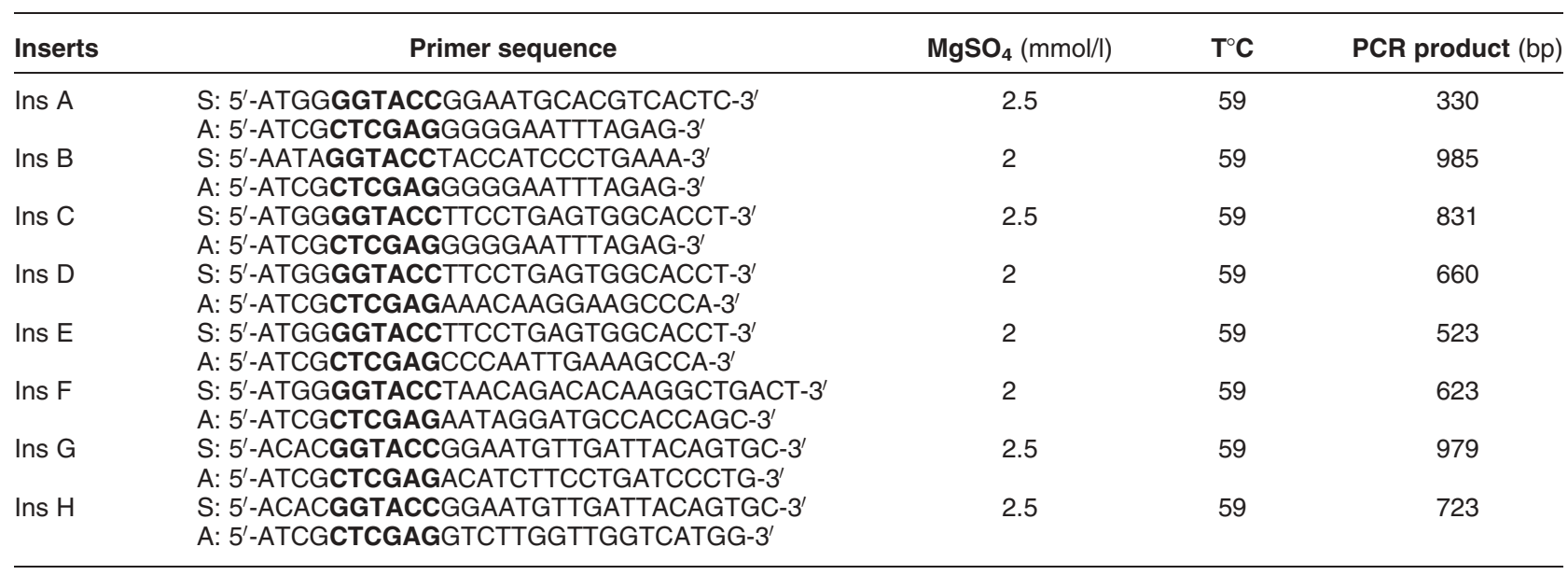

S: sense (kpnl restriction site: $5^{\prime}$-GGTACC- $\left.3^{\prime}\right)$.

A: antisense (Xhol restriction site: $5^{\prime}$-CTCGAG-3').

$\mathrm{MgSO}_{4}: \mathrm{PCR} \mathrm{MgSO}_{4}$ concentration.

$\mathrm{T}^{\circ} \mathrm{C}$ : PCR annealing temperature. 
A

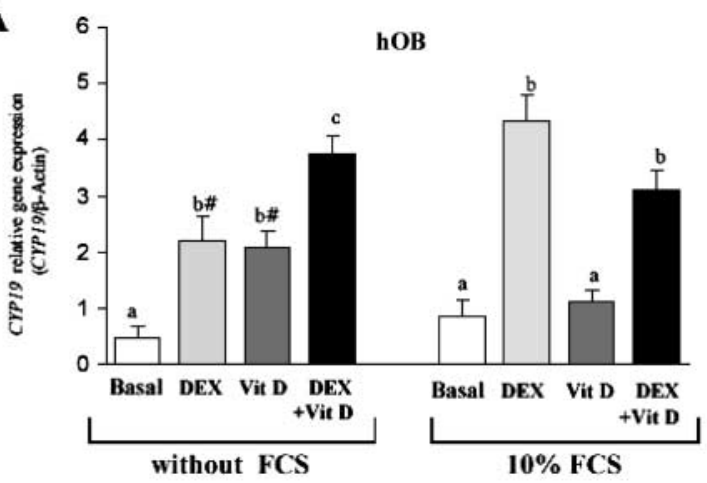

\section{B}

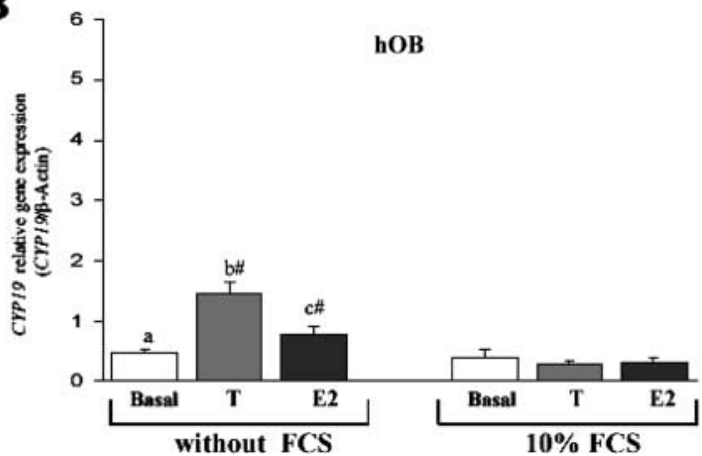

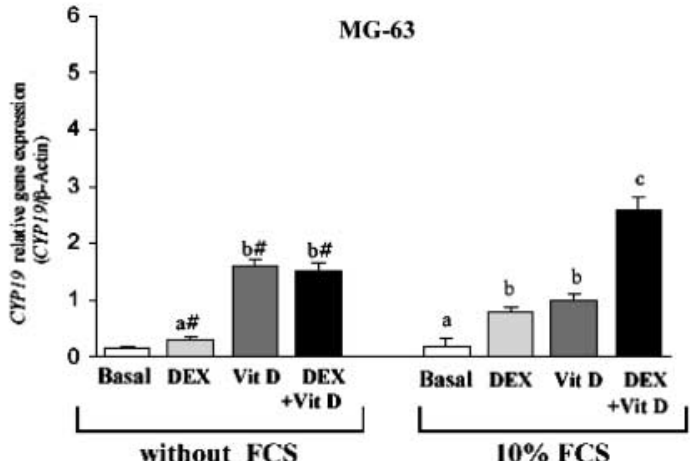

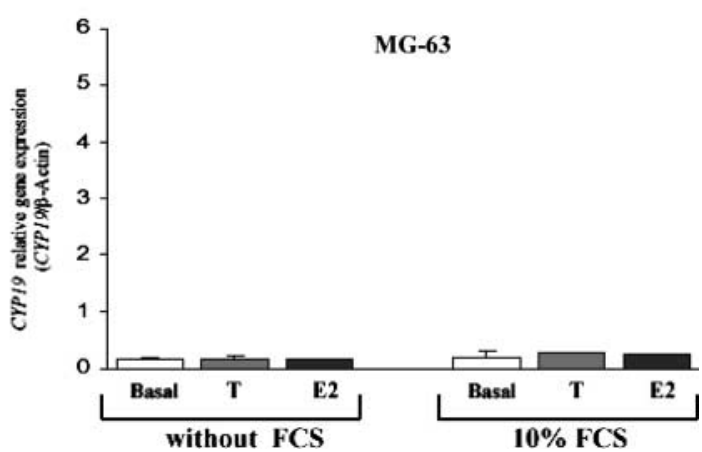

Figure 1 Quantitative analysis of aromatase mRNA levels under different hormone treatments. Aromatase transcripts were quantified by real-time PCR analysis from primary human osteoblasts of four donors and from MG-63 cells. All experiments were performed in duplicate. Treatments and culture conditions are indicated below the graphs and cell types are indicated above. Results are expressed as means \pm S.E. of four replicates of CYP19 relative gene expression. (A) Effects of dexamethasone (DEX) and vitamin D (Vit D). (B) Effects of testosterone (T) and 17 $\beta$-estradiol (E2). Significant differences among treatments are indicated by different letters (a-c, Student-Newman-Keuls, $P<0.05)$ and significant differences of a given treatment in the absence or presence of $10 \%$ FCS are indicated by the \# symbol (Student's $t$-test, $P<0.02$ ). hOB: human osteoblasts; Basal: cell culture without treatment.

Vit D resulted in significant stimulation of CYP19 expression (4.8-fold in primary osteoblasts for DEX; and 4.5-fold in primary osteoblasts and 10.5-fold in MG-63 for Vit D). However, while DEX stimulation was enhanced by $10 \%$ FCS, Vit D stimulation was inhibited by it. Similar results were obtained with $10^{-8} \mathrm{~mol} / \mathrm{l}$ of each treatment (data not shown).

Testosterone or E2 also stimulated CYP19 transcription, but to a much lesser extent (3.1-fold and 1.6-fold respectively) and only in primary osteoblasts in the absence of FCS (Fig. 1B). Control cultures for the steroid hormone experiments were carried out by adding ethanol and the results were the same as those of the treatment-free experiments (data not shown). Similarly, treatment with TNF- $\alpha$ resulted in reduced CYP19 transcript levels, but only in primary osteoblasts in the absence of FCS (not shown). Treatments with IL-1 $\alpha$ or leptin proved ineffective in this system.

\section{Functional analysis of different CYP19 upstream regions}

Several CYP19 promoters were cloned upstream of the luciferase reporter gene of the pGL3Basic vector and were transiently transfected in MG-63 cells to assay functionality. Eight different constructs (named A to $\mathrm{H})$ were obtained (Fig. 2), three of which (A-C) contained promoter pII, two (D, E) promoter I.3 alone, one (F) promoter I.6, and two $(\mathrm{G}, \mathrm{H})$ promoter I.4. Luciferase assays were performed from cultures maintained with or without $10 \%$ FCS. The pII promoter, up to exon I. 3 (construct A), displayed the highest activity of all: more than 2.8 times higher than promoter I.4 (construct $G)$, the second most active. When $\sim 600 \mathrm{bp}$ of upstream sequence were added to promoter pII (construct B), a drastic reduction (8.5-fold) in activity was observed, suggesting the presence of one or more repressor elements. The activity of construct B was partly recovered (2-fold) when $\sim 160 \mathrm{bp}$ of exon I.6 were removed (construct $\mathrm{C}$ ), indicating that this exon contains at least one repressor element. The activity of promoter I.3 was assayed singly with construct D, in which exon I.3 was directly fused to the luciferase gene.

This construct displayed the least activity of all. Indeed, by removing $137 \mathrm{bp}$ of exon I.3 (positions -207 to -71 ; construct E) a 3 -fold increase in promoter I.3 activity was observed, suggesting the presence of 


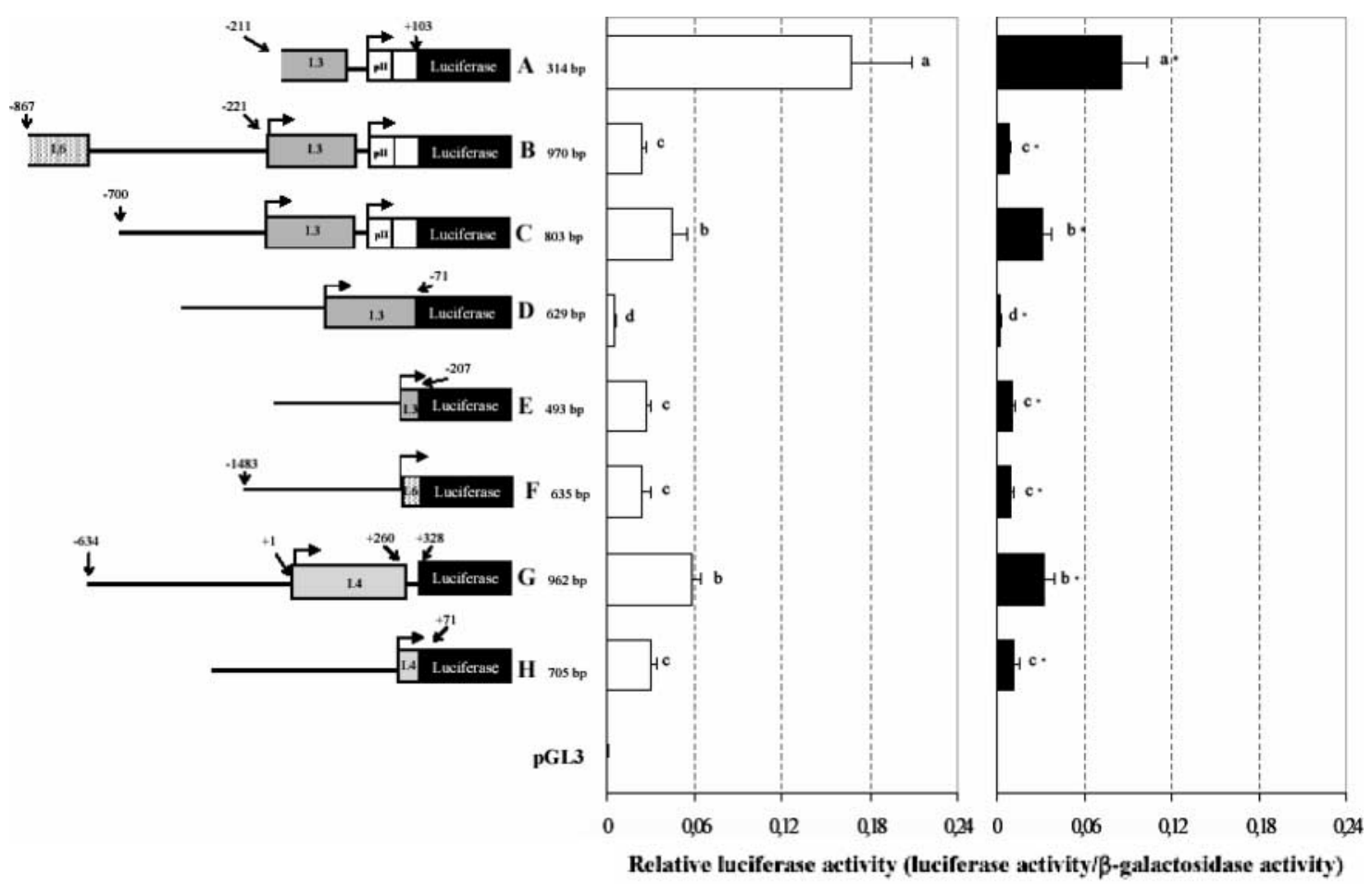

Figure 2 Luciferase assays of different CYP19 promoter constructs. Relative luciferase activities (right) measured in MG-63 cells co-transfected with one pGL3-CYP19 construct (A, B, C, D, E, F, G or H; left) and the pSV- $\beta$ Gal plasmid. Boxes show non-translated exons of CYP19 and the luciferase reporter gene. Arrows above the boxes show alternative transcription initiation sites. The length of CYP19 promoter sequence (bp) is indicated for each construct. The experiments were performed in the absence (empty bars) or the presence (black bars) of $10 \%$ FCS. Results are expressed as mean values \pm S.E. of relative luciferase activity. Transfection experiments were replicated four or more times for each construct. Different letters $(a-d)$ indicate significant differences of activity between constructs (Mann-Whitney U-test, $P<0.03$ ) and the * symbol indicates significant differences of a given construct in the absence or presence of $10 \%$ FCS (Mann-Whitney U-test, $P<0.05$ ).

specific exon I.3 repressors. Promoter I.6 (included in construct F, together with $20 \mathrm{bp}$ of exon I.6) displayed moderate activity. Finally, promoter I.4 was the second most active (construct $\mathrm{G}$ ). However, deletion of $257 \mathrm{bp}$ of exon I.4, as well as part of the following intron (positions +71 to +328 ; construct $\mathrm{H}$ ), resulted in a 2-fold reduction in activity, indicating the possible presence of enhancer elements(s). When the eight constructs were assayed in the presence of $10 \%$ FCS, the same relative activities were observed, although the absolute values were reduced by half (Fig. 2).

\section{Effects of Vit D and DEX on the different constructs}

Luciferase assays of the eight constructs were also performed under treatment with either DEX, Vit D or DEX + Vit D (Fig. 3). In cultures without FCS, DEX significantly enhanced expression by constructs containing either promoter I.3 (B-D) or I.4 (G), while Vit D only enhanced activity from promoter I.3 (B-D). In the presence of $10 \%$ FCS, DEX stimulation occurred in promoters I.3 and I.4, and was noticeably stronger. By contrast, Vit D + 10\% FCS resulted in cancellation of Vit D stimulation.

\section{Discussion}

In this study we have shown that out of seven different hormone and cytokines, only Vit D and DEX were potent stimulators of CYP19 transcription, while testosterone and E2 were moderate stimulators. Moreover, we have defined promoter regions of CYP19 relevant to its expression in hOBs, in basal conditions and in response to Vit D and DEX treatments.

Consistently with results obtained in our previous study using primary hOBs (22), luciferase assays showed that pII, I. 3 and I.4 promoters were active in MG-63 cells. Here we report that the sequence containing promoter pII up to exon I.3 $(-221$ to +1$)$ displayed high activity in MG-63 cells. A similar region ( -278 and -43 ) has been shown to mediate human CYP19 gene expression in the ovary. This region is known to contain two regulatory elements, a cAMP-responsive element-like sequence $(-208 /-199)$ and a steroidogenic factor- 1 site $(-132 /-125)$ (26). In addition, our results showed that the region located between -867 and -211 bp contains repressor element(s) for this promoter activity in MG-63 cells. An inhibitory effect of $5^{\prime}$ sequences, located between -2700 and -278 bp on pII activity, has similarly been described 


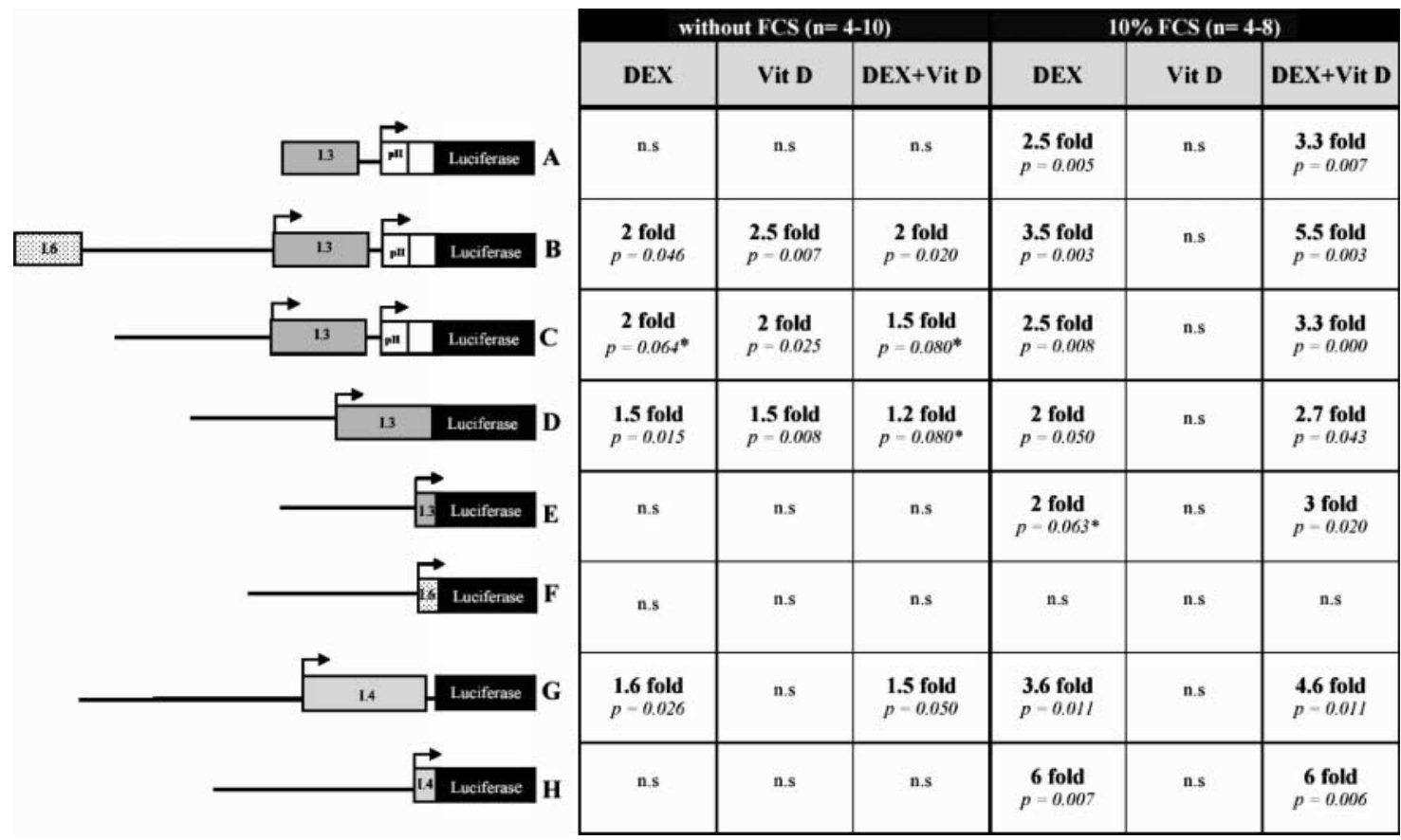

Figure 3 Luciferase assays of different CYP19 promoter constructs under different treatments. MG-63 cells, co-transfected with one pGL3-CYP19 construct (A, B, C, D, E, F, G or H; left) and the pSV- $\beta$ Gal plasmid, were treated with vitamin D (Vit D), dexamethasone (DEX), or Dex + Vit D in either the absence or presence of $10 \%$ FCS. For a given treatment and culture medium, relative luciferase activity for each construct was measured and compared with the same construct activity in the absence of treatment (Mann-Whitney U-test; *marginal $P$-value; n.s.: not significant).

in ovarian tissue (27). Transcriptional activity of pII or I. 3 promoters was partly recovered when exon I.6 was removed, indicating that this exon contains some of the repressor elements. Our results therefore underscore the importance of exon I.6 in the regulation of pII or I. 3 promoter activity in osteoblasts. Regarding promoter I.4, an important activity was observed in MG-63 cells, consistent with our previous findings in hOBs and those of other groups $(15,16,22)$. Additionally the presence of an enhancer element in exon I.4 $(+71$ to +328$)$ was demonstrated. This region is known to contain an Sp1 site (28). Regarding promoter I.3, we observed the presence of specific repressors within exon I.3 $(-207$ to -71$)$.

In this study, we observed that both Vit D and DEX treatments increased the transcriptional levels of CYP19 in cultured normal hOBs and in MG-63 cells. Moreover, FCS exerted an inhibitory effect on Vit D stimulation of CYP19 gene expression. The stimulation of CYP19 gene by Vit D alone had been described previously by our group and by others $(22,29,30)$. This serum effect might explain the lack of CYP19 stimulation by Vit D observed in other studies $(15,20,24)$.

Results from luciferase assays indicate that DEX and Vit D enhance promoter activity from I.3 and I.4, as previously reported (24). This activation of I.4 promoter activity has similarly been described in the stromal cells of adipose tissue as well as in hOBs $(22,24,25,31)$. A glucocorticoid-response element in the I.4 promoter could well be involved in this osteoblast response (24). No Vit $\mathrm{D}$ response element has yet been identified in the -867 to +1 region of CYP19 (Transfac database, www.generegulation.com/pub/databases.html\#transfac).

The effects of treatments with testosterone or E2 confirm previously reported findings (22). Both treatments increased CYP19 gene expression in hOBs, and FCS showed an inhibitory effect on this stimulation. We have also observed that TNF- $\alpha$ decreased transcriptional levels of CYP19 in primary hOBs but had no effect in MG-63 cells, while IL-1 $\beta$ did no exert any effect. These results differ from other published works $(32,33)$, where stimulation or no effect in aromatase mRNA expression by IL-1 $\beta$ and TNF- $\alpha$ was described in HOS cells and osteoblast-like cells. The TNF- $\alpha$ inhibitory effect in CYP19 gene expression might be in agreement with its local resorptive action in bone.

Previous studies have demonstrated that leptin stimulates estrogen production by increasing aromatase expression and activity in human luteinized granulosa cells (34), adipose stromal cells (35) and the MCF-7 cell line (36). We and others have observed that hOBs do express the leptin receptor mRNA (37-39). However, leptin had no effect in our experiments, either in primary hOBs or in MG-63 cells. These results suggest leptin has no effect on CYP19 gene expression in hOBs, and whether leptin acts on other aspects of osteoblast function remains an open issue. 
This study is a first step to explore promoter regions involved in CYP19 gene expression in hOBs. However, further work is needed to define the mechanisms of transcription regulation in more detail and to identify the nuclear factors involved.

In conclusion, we show a stimulatory effect of Vit D and DEX on CYP19 gene expression in primary hOBs and MG-63 cells, and demonstrate the functional relevance of several upstream regions in this hormonal regulation. These results contribute to unraveling the complexity of CYP19 expression in hOBs.

\section{Acknowledgements}

We would like to thank Dr J C Monllau for providing samples. R Rycroft provided editorial assistance. M B is the recipient of a fellowship from the Spanish Ministerio de Ciencia y Tecnología. This study was supported by grants from the Spanish Ministerio de Ciencia y Tecnología (PM1999-0131-C02-01) and the Spanish Ministerio de Educación y Ciencia (SAF2004-06085) and, in part, from the Institut Municipal d'Investigació Mèdica by an unrestricted grant from Lilly España.

\section{References}

1 Sims NA, Dupont S, Krust A, Clement-Lacroix P, Minet D, RescheRigon M, Gaillard-Kelly M \& Baron R. Deletion of estrogen receptors reveals a regulatory role for estrogen receptors-beta in bone remodeling in females but not in males. Bone 200230 18-25.

2 Lindberg MK, Moverare S, Skrtic S, Alatalo S, Halleen J, Mohan S, Gustafsson JA \& Ohlsson C. Two different pathways for the maintenance of trabecular bone in adult male mice. Journal of Bone and Mineral Research 200217 555-562.

$3 \mathrm{OzOK}$, Hirasawa G, Lawson J, Nanu L, Constantinescu A, Antich PP, Mason RP, Tsyganov E, Parkey RW, Zerwekh JE \& Simpson ER. Bone phenotype of the aromatase deficient mouse. Journal of Steroid Biochemistry and Molecular Biology 200179 49-59.

4 Miyaura C, Toda K, Inada M, Ohshiba T, Matsumoto C, Okada T, Ito M, Shizuta Y \& Ito A. Sex- and age-related response to aromatase deficiency in bone. Biochemical and Biophysical Research Communications $20012801062-1068$.

5 Smith EP, Boyd J, Frank GR, Takahashi H, Cohen RM, Specker B, Williams TC, Lubahn DB \& Korach KS. Estrogen resistance caused by a mutation in the estrogen-receptor gene in a man. New England Journal of Medicine 1994331 1056-1061.

6 Rochira V, Balestrieri A, Faustini-Fustini M \& Carani C. Role of estrogen on bone in the human male: insights from the natural models of congenital estrogen deficiency. Molecular and Cellular Endocrinology $2001 \mathbf{1 7 8} 215-220$.

7 Meinhardt U \& Mullis PE. The aromatase cytochrome P-450 and its clinical impact. Hormone Research 200257 145-152.

8 Thompson EA Jr \& Siiteri PK. The involvement of human placental microsomal cytochrome P-450 in aromatization. Journal of Biological Chemistry 1974249 5373-5378.

9 Corbin CJ, Graham-Lorence S, McPhaul M, Mason JI, Mendelson CR \& Simpson ER. Isolation of a full-length cDNA insert encoding human aromatase system cytochrome P-450 and its expression in nonsteroidogenic cells. PNAS $1988 \mathbf{8 5} 8948-8952$.

10 Simpson ER \& Davis SR. Minireview: aromatase and the regulation of estrogen biosynthesis - some new perspectives. Endocrinology $20011424589-4594$.
11 Kamat A, Hinshelwood MM, Murry BA \& Mendelson CR. Mechanisms in tissue-specific regulation of estrogen biosynthesis in humans. Trends in Endocrinology and Metabolism 200213 122-128.

12 Toda K, Simpson ER, Mendelson CR, Shizuta Y \& Kilgore MW. Expression of the gene encoding aromatase cytochrome P450 (CYP19) in fetal tissues. Molecular Endocrinology 1994 8 210-217.

13 Sebastian S, Takayama K, Shozu M \& Bulun SE. Cloning and characterization of a novel endothelial promoter of the human CYP19 (aromatase P450) gene that is up-regulated in breast cancer tissue. Molecular Endocrinology 200216 2243-2254.

14 Simpson ER, Zhao Y, Agarwal VR, Michael MD, Bulun SE \& Hinshelwood MM. Aromatase expression in health and disease. Recent Progress in Hormone Research 199752 185-213.

15 Tanaka S, Haji M, Takayanagi R, Tanaka S, Sugioka Y \& Nawata H. 1,25Dihydroxyvitamin D3 enhances the enzymatic activity and expression of the messenger ribonucleic acid for aromatase cytochrome P450 synergistically with dexamethasone depending on the vitamin D receptor level in cultured human osteoblasts. Endocrinology 1996137 1860-1869.

16 Shozu M \& Simpson ER. Aromatase expression of human osteoblastlike cells. Molecular and Cellular Endocrinology 1998139 117-129.

17 Purohit A, Flanagan AM \& Reed MJ. Estrogen synthesis by osteoblast cell lines. Endocrinology 1992131 2027-2029.

18 Shimodaira K, Fujikawa H, Okura F, Shimizu Y, Saito H \& Yanaihara T. Osteoblast cells (MG-63 and HOS) have aromatase and 5 alfa reductase activities. Biochemistry and Molecular Biology International 199639 109-116.

19 Jakob F, Siggelkow H, Homann D, Köhrle J, Adamski J \& Schütze N. Local estradiol metabolism in osteoblast- and osteoclast-like cells. Journal of Steroid Biochemistry and Molecular Biology 199761 167-174.

20 Tanaka S, Haji M, Nishi Y, Yanase T, Takayanagi R \& Nawata H. Aromatase activity in human osteoblast-like osteosarcoma. Calcified Tissue International 199352 107-109.

21 Janssen JMMF. Estradiol formation by human osteoblasts via multiple pathways: relation with osteoblast funtion. Journal of Cellular Biochemistry 199975 528-537.

22 Enjuanes A, Garcia-Giralt N, Supervia A, Nogues X, Mellibovsky L, Carbonell J, Grinberg D, Balcells S \& Diez-Perez A. Regulation of CYP19 gene expression in primary human osteoblasts: effects of vitamin D and other treatments. European Journal of Endocrinology 2003148 519-526.

23 Shozu M, Sumitani H, Murakami K, Segawa T, Yang HJ \& Inoue M. Regulation of aromatase activity in bone-derived cells: possible role of mitogen-activated protein kinase. Journal of Steroid Biochemistry and Molecular Biology 200179 61-65.

24 Takayanagi R, Goto K, Suzuki S, Tanaka S, Shimoda S \& Nawata H. Dehydroepiandrosterone (DHEA) as a possible source for estrogen formation in bone cells: correlation between bone mineral density and serum DHEA-sulfate concentration in postmenopausal women, and the presence of aromatase to be enhanced by 1,25dihydroxyvitamin D3 in human osteoblasts. Mechanisms of Ageing and Development 2002123 1107-1114.

25 Shozu M, Zhao Y \& Simpson ER. TGF-betal stimulates expression of the aromatase (CYP19) gene in human osteoblast-like cells and THP-1 cells. Molecular and Cellular Endocrinology $2000160123-133$.

26 Michael MD, Michael LF \& Simpson ER. A CRE-like sequence that binds CREB and contributes to CAMP-dependent regulation of the proximal promoter of the human aromatase P450 (CYP19) gene. Molecular and Cellular Endocrinology 1997134 147-156.

27 Hinshelwood MM, Smith ME, Murry BA \& Mendelson CR. A 278 bp region just upstream of the human CYP19 (aromatase) gene mediates ovary-specific expression in transgenic mice. Endocrinology 2000141 2050-2053.

28 Zhao Y, Mendelson CR \& Simpson ER. Characterization of the sequences of the human CYP19 (aromatase) gene that mediate regulation by glucocorticoids in adipose stromal cells and fetal hepatocytes. Molecular Endocrinology 19959 340-349.

29 Kinuta K, Tanaka H, Moriwake T, Aya K, Kato S \& Seino Y. Vitamin D is an important factor in estrogen biosynthesis of both female and male gonads. Endocrinology 2000141 1317-1324. 
30 Sylvia VL, Gay I, Hardin R, Dean DD, Boyan BD \& Schwartz Z. Rat costochondral chondrocytes produce 17 beta-estradiol and regulate its production by 1alpha,25(OH)(2)D(3). Bone $20023057-63$.

31 Shozu M, Sumitani H, Segawa T, Yang HJ, Murakami K, Kasai T \& Inoue M. Overexpression of aromatase P450 in leiomyoma tissue is driven primarily through promoter I.4 of the aromatase P450 gene (CYP19). Journal of Clinical Endocrinology and Metabolism $2002872540-2548$.

32 Morioka M, Shimodaira K, Kuwano Y, Fujikawa H, Saito H \& Yanaihara T. Effect of interleukin-1 beta on aromatase activity and cell proliferation in human osteoblast-like cells (HOS). Biochemical and Biophysical Research Communications 2000268 60-64.

33 Shozu M, Zhao Y \& Simpson ER. Estrogen biosynthesis in THP1 cells is regulated by promoter switching of the aromatase (CYP19) gene. Endocrinology 1997138 5125-5135.

34 Catalano S, Marsico S, Giordano C, Mauro L, Rizza P, Panno ML \& Ando S. Leptin enhances, via AP-1, expression of aromatase in the MCF-7 cell line. Journal of Biological Chemistry $2003 \mathbf{2 7 8}$ 28668-28676.

35 Kitawaki J, Kusuki I, Koshiba H, Tsukamoto K \& Honjo H. Leptin directly stimulates aromatase activity in human luteinized granulosa cells. Molecular Human Reproduction $19995708-713$.
36 Magoffin DA, Weitsman SR, Aagarwal SK \& Jakimiuk AJ. Leptin regulation of aromatase activity in adipose stromal cells from regularly cycling women. Ginekologia Polska 199970 1-7.

37 Enjuanes A, Supervia A, Nogues X \& Diez-Perez A. Leptin receptor (OB-R) gene expression in human primary osteoblasts: confirmation. Journal of Bone and Mineral Research 2002171135.

38 Reseland JE, Syversen U, Bakke I, Qvigstad G, Eide LG, Hjertner O, Gordeladze JO \& Drevon CA. Leptin is expressed in and secreted from primary cultures of human osteoblasts and promotes bone mineralization. Journal of Bone and Mineral Research 200116 $1426-1433$.

39 Gordeladze JO, Drevon CA, Syversen U \& Reseland JE. Leptin stimulates human osteoblastic cell proliferation, de novo collagen synthesis, and mineralization: Impact on differentiation markers, apoptosis, and osteoclastic signaling. Journal of Cellular Biochemistry $2002 \mathbf{8 5} 825-836$.

Received 2 June 2005

Accepted 1 September 2005 